\title{
Low bone mineral density in children and adole- scents with cancer
}

\author{
Hye Young Jin, MD, PhD, \\ Jun Ah Lee, MD, PhD
}

Department of Pediatrics, Center for Pediatric Cancer, National Cancer Center, Goyang, Korea
Received: 30 December, 2019

Revised: 2 February, 2020

Accepted: 10 February, 2020

Address for correspondence: Jun Ah Lee, MD, PhD

Department of Pediatrics, Center for Pediatric Cancer, National Cancer Center, 323 Ilsan-ro, Ilsandong-gu, Goyang 10408, Korea Tel: +82-31-920-1604 Fax: +82-31-920-1244 E-mail: junahlee@ncc.re.kr https://orcid.org/0000-0003-33109566

\begin{abstract}
Maximizing accumulation of bone mass during childhood and adolescence is essential to attaining optimal peak bone mass. Childhood cancer survivors (CCS) have lower bone mineral density (BMD) than the general population. Chemotherapeutic agents including steroids and radiotherapy can affect BMD. Cancer itself, hormonal insufficiency, a poor nutritional state, and a deficit of physical activities during or after treatment also influence BMD in CCS, resulting in failure to achieve appropriate peak bone mass. Low BMD in childhood and adolescence can lead to osteoporosis in adult life and complications such as bone pain, bone deformity, and fractures. Thus, BMD in CCS should be monitored with appropriate intervention. Adequate intake of calcium and vitamin $D$ and an increase in physical activity are recommended. Timely supplements of hormones are needed in some cases. Some publications have reported that bisphosphonate therapies using pamidronate or alendronate were well tolerated in CCS and helped increase BMD.
\end{abstract}

Keywords: Peak bone mass, Childhood cancer survivors, Bone mineral density

\section{Introduction}

As the survival rates of childhood cancer increase, there has been a substantial increase in the number of children and adolescents with chronic complications. Survivors of childhood cancer are at risk for late adverse effects of cancer treatment. Endocrine and metabolic and skeletal sequelae are described in 50\% of childhood cancer survivors (CCS). ${ }^{1)}$ CCS have increased risk of low bone mineral density (BMD) because cancer treatments interfere with gains in BMD. Previous studies have included small numbers of cases, various age groups, heterogeneous treatments, different sites of BMD measurement, and different definitions of low BMD. ${ }^{2-4)}$ The terminology and definitions of low BMD in CCS are diverse. The World Health Organization's (WHO) definitions of osteopenia and osteoporosis are based on T-scores, which are used to compare patient BMD with the maximum BMD of young adults, applying only to postmenopausal women. Some have defined a $z$-score $<-1.0$ as osteopenia (low BMD) and $<-2.5$ as osteoporosis (significantly low BMD), ${ }^{5,6)}$ The International Society for Clinical Densitometry (ISCD) recommends the use of "low BMD for chronological age" when the BMD $z$-score is lower than -2.0." Last updated in 2019, diagnosis of osteoporosis in children and adolescents requires the presence of both a clinically significant fracture history and BMD $z$-score less than or equal to -2.0. Vertebral compression fractures without local disease or high-energy trauma are also indicative of osteoporosis. ${ }^{8}$ Osteoporosis in adulthood has its origins in childhood and adolescence, which is an important period for optimizing peak bone mass (PBM), ${ }^{9}$ which is the maximum amount of bone a person has during their lifetime and a crucial determinant of osteoporotic fracture risk. ${ }^{10)} \mathrm{A}$ considerable part of PBM is determined by genetic factors. CCS fail to achieve PBM due to cancer itself, chemotherapy, malnutrition, and decreased activity. Low BMD in childhood and adolescents is a risk factor 
for fractures in youth and osteoporosis later in life. ${ }^{11)}$ In this article, we address the causes, prevalence, and management of low BMD in children and adolescents with cancer.

\section{Causative factors of low BMD in children and adolescents with cancer}

Cancer itself causes BMD deficits. Low BMD at the time of diagnosis of pediatric cancer was primarily reported in patients with acute lymphoblastic leukemia (ALL) ${ }^{12,13)}$ and neuroblastoma. ${ }^{14)}$ Leukemic cell proliferation in the bone marrow and cytokine-mediated osteoclast activity are suggested as causes of low BMD. ${ }^{12}$ Patients with primary bone tumors, including osteosarcoma and Ewing sarcoma, have low BMD in the affected sites. ${ }^{15-17)}$

Effects of chemotherapeutic agents on bone metabolism have been widely studied. The agents most frequently used to treat pediatric cancer are corticosteroids, alkylating agents, antimetabolites, and antibiotics. Corticosteroids inhibit the activity of osteoblasts and osteocytes, resulting in decreased bone formation and repair of microdamaged bones. Moreover, corticosteroids increase osteoclastic bone resorption and inhibit $1 \alpha$-hydroxylation of vitamin $\mathrm{D} .{ }^{18)}$ In patients with ALL, those receiving a total corticosteroid dose greater than $9 \mathrm{~g} / \mathrm{m}^{2}$ were more likely to have decreased BMD that did not recover after completing chemotherapy. ${ }^{19)}$ In patients with malignant lymphoma, prednisone dose greater than $20 \mathrm{~g} / \mathrm{m}^{2}$ is a risk factor for osteopenia. ${ }^{5}$

Patients with ovary or testis tumors are at risk of primary hypogonadism, affecting BMD. Alkylating agents, such as cyclophosphamide and ifosfamide, also cause primary hypogonadism and result in BMD deficits. ${ }^{20)}$ Estrogen and androgens influence the growth and maintenance of bone. ${ }^{21)}$ Estrogen has a role in attaining PBM in both sexes. ${ }^{21}$ Androgens enlarge the cross-sectional area of long bones and increase mechanical strength. ${ }^{21)}$ Doses of alkylating agents are closely related to degree of gonadal impairment. A CCS study developed a method to combine and compare cumulative doses of different alkylating agents using cyclophosphamide equivalent dose (CED). ${ }^{22)}$ The St. Jude Lifetime Cohort study reported that high-dose alkylating agents $\left(\mathrm{CED} \geq 80 \mathrm{~g} / \mathrm{m}^{2}\right)$ and ovarian radiotherapy at any dose are associated with premature ovarian insufficiency. ${ }^{23)}$ For males, testicular radiotherapy at any dose and exposure to alkylating agents $\left(C E D \geq 40 \mathrm{~g} / \mathrm{m}^{2}\right)$ were independent risk factors for Leydig cell failure, defined as testosterone $<250 \mathrm{ng} / \mathrm{dL}$ and luteinizing hormone $>9.85 \mathrm{IU} / \mathrm{L} .{ }^{24)}$ Methotrexate has a cytotoxic effect on the activity of osteoblasts and stimulates osteoclasts recruitment. It has been reported that a total cumulative dose greater than $4 \mathrm{~g} / \mathrm{m}^{2}$ was associated with failure to recover to a normal BMD after completion of chemotherapy. ${ }^{15,19)}$ In contrast, a recent study demonstrated that methotrexate exposure is not an independent risk factor for a significant decrease in BMD $(z$-score $\leq-2)$. It is suggested that methotrexate lowers BMD but does not present a significant risk for $z$-score $\leq-2{ }^{25)}$

Hematopoietic stem cell transplantation (HSCT) also affects BMD. Bone loss occurred and continued frequently in the first year following allogeneic HSCT. ${ }^{26)}$ At 6 months after HSCT, nearly $50 \%$ of patients had osteopenia (T-score $\leq-1)$ at the femoral neck or lumbar spine. ${ }^{27)}$ Approximately $1 / 3$ of patients who had undergone allogeneic HSCT in childhood had reduced BMD before reaching adulthood, with a high prevalence of asymptomatic vertebral compression fractures. ${ }^{28}$ Pediatric patients with solid tumors (osteosarcoma, Ewing sarcoma, neuroblastoma) who underwent autologous HSCT showed a significant decrease in whole-body BMD $z$-score. ${ }^{29)}$ Multiple factors are involved in the pathogenesis of bone loss following HSCT, including impairment of gonadal and pituitary hormone secretion by high-dose chemotherapy, immobilization, poor oral intake, vitamin D deficiency, and use of calcineurin inhibitors and corticosteroids for graft-versus-host disease. ${ }^{26)}$ High-dose chemotherapy for HSCT shows dose-dependent toxicity on bone marrow stromal osteoprogenitors. ${ }^{30)}$ Patients who underwent HSCT at a younger age and allogeneic HSCT had a significantly higher risk of low BMD of the spine. ${ }^{31,32)}$

Endocrine sequelae resulting from radiotherapy cause a significant decrease in BMD. Negative effects of radiotherapy on BMD have been frequently reported in children with brain tumors. Patients with a tumor in the sellar or suprasellar region such as craniopharyngioma, germinoma, or low-grade glioma are highly likely to develop growth hormone (GH) deficiency or central hypogonadism. ${ }^{20)}$ Radiation at the hypothalamicpituitary axis and total body irradiation (TBI) can lead to GH deficiency, affecting bone growth and BMD. ${ }^{1,2,33)} \mathrm{GH}$ and insulin-like growth factor I are important for maintaining bone mass because both independently contribute to bone remodeling and apposition. ${ }^{34)}$ The severity of GH deficiency depends on patient age, dose, and fraction of radiation. A young age, higher radiation dose ( $\geq 18 \mathrm{~Gy})$, pretransplant radiation, $\mathrm{TBI} \geq 10$ Gy in a single fraction, and TBI $\geq 12$ Gy fractionated increase the risk of GH deficiency. ${ }^{35)}$ Gonadotropin deficiency occurs in patients who received TBI $\geq 30$ Gy at the brain and may occur in those who received lower radiation doses with longer follow-up. ${ }^{35)}$ In addition to hormonal effects, radiation directly affects bone health at the local site of exposure and results in abnormalities in bone growth and an increased risk of fractures. ${ }^{36,37)}$

Nutrition and physical activity are essential to obtaining PBM. ${ }^{38)}$ In childhood cancer patients, physical activities are decreased due to prolonged periods of hospitalization and surgery, causing bone resorption and negatively affecting BMD. ${ }^{39)}$ In a study with survivors of ALL, reduced exercise capacity was associated with reduced spine BMD. ${ }^{39)}$

\section{Prevalence of low BMD in childhood cancer}

The prevalence of low BMD among CCS ranges from 9\%$51 \%{ }^{2-4)}$ Multiple factors contribute to development of low BMD in patients with cancer, as described above. In a collaborative 
cohort study of St. Jude and Dutch CCS, shorter height, lower weight, younger attained age, use of alkylating agent, and prior exposure to cranial and abdominal irradiation were closely related with low BMD $(z$-score $\leq-1) .{ }^{4)}$ In children with cancer, treatments affect bone health during the first year, causing a significant decrease in BMD. BMD decreased during the first 6 months in patients with leukemia or lymphoma and during the latter 6 months of therapy for those with solid tumors. ${ }^{29)}$ Thus, the prevalence of low BMD depends on subject risk factors and assessment timing of BMD. Nevertheless, decreased BMD is a common finding in survivors of leukemia, lymphoma, brain tumors, solid tumors, and those who undergo HSCT (Table 1).

\section{ALL and lymphoma}

At the time of diagnosis, significantly reduced BMD ( $z$-score: $-0.60 \pm 1.55$ ) was observed at the lumbar spine. ${ }^{12)}$ Chemotherapy for ALL includes corticosteroids and methotrexate, and a decrease in BMD occurs during chemotherapy. In a study of childhood leukemia and lymphoma survivors, lumbar spine BMD was low $(z$-score $<-1)$ in $17.2 \%$ of subjects. ${ }^{40)}$ Also, $10.8 \%$ of survivors aged 15-19 years at diagnosis had very low BMD ( $z$-score $<-2)$, indicating that those of an older age were at high risk for low BMD. ${ }^{40)}$ A pharmacogenetic study evaluated the influence of single nucleotide polymorphisms in 4 genes (i.e., vitamin D receptor, collagen type I alpha 1, estrogen receptor 1 , and glucocorticoid receptor) on body composition, BMD, and fracture risk. The vitamin D receptor gene (VDR) 5'-end (Cdx2/GATA) haplotype 3 was a risk factor for lower lumbar spine BMD during treatment of pediatric ALL. ${ }^{41)}$ In children with ALL, skeletal complications, such as bone pain, osteonecrosis, fracture, loss of mobility, bone deformation, and osteopenia, have been frequently reported during or after treatment. ${ }^{42)}$ Osteonecrosis is the best known skeletal complication, but fractures and bone pain are also frequent. In a case series of 122 pediatric patients with ALL, the 5 -year incidence of fractures and bone pain was $13.5 \%$ and $12.3 \%$, respectively. ${ }^{42}$

BMD was decreased in long-term survivors of Hodgkin disease and non-Hodgkin lymphoma. A BMD $z$-score $<-1.0$ was reported in $41 \%$ of patients with Hodgkin disease and $50 \%$ of patients with non-Hodgkin lymphoma at the lumbar spine after 24.1 and 14.1 years of follow-up, respectively. ${ }^{5,43)}$ In addition to high cumulative dose of corticosteroid, mechlorethamine, vincristine, and procarbazine for treating malignant lymphoma also cause low BMD.

\section{Brain and other solid tumors}

Low BMD is a common finding among brain tumor patients treated in childhood. ${ }^{33,44)}$ Causes of low BMD are multifactorial, including craniospinal irradiation, GH deficiency, massive corticosteroids doses, and use of alkylating agents. Researchers have found that $23.6 \%-33 \%$ of patients with brain tumors treated in childhood had reduced BMD, with a total body BMD $z$-score $<-2.0 .^{33,44)}$ In a case series of 28 intracranial germ cell tumor survivors, the prevalence of osteoporosis and osteopenia was $25.0 \%$ and $42.9 \%$, respectively. In addition to radiation, risk factors included male sex, a low lean mass, and adult GH replacement. $^{45)}$

Low BMD was reported in survivors of various other solid tumors. Ten of 48 long-term survivors of highly malignant osteosarcoma were osteoporotic, and 21 of 48 were osteopenic, according to the WHO definition. ${ }^{15)}$ Reduced lumbar BMD $(z$-score $<-1.0)$ was also reported in $28.3 \%-43.6 \%$ of survivors of osteosarcoma or Ewing sarcoma. ${ }^{16,17)}$ In a Korean study evaluating the BMD of 9 osteosarcoma patients before and after treatment, 44\% showed decreased lumbar BMD and $78 \%$ showed decreased femur neck BMD after adjuvant chemotherapy, while all 8 healthy controls showed increased lumbar and femur BMD. ${ }^{46)}$ Young age at diagnosis, male sex, and decreased lean mass are risk factors of osteoporosis in long-term survivors of osteosarcoma. ${ }^{47)}$ In children with neuroblastoma, three of 27 patients showed low lumbar BMD $(z$-score $<-2.0)$ at the time of diagnosis, necessitating BMD assessment during the early course of the disease. ${ }^{14)}$ The incidence of osteopenia $(z$-score $<-1.0)$ was $27 \%$ in long-term survivors of Wilms tumor. $^{48)}$

Table 1. Korean data on low BMD in childhood cancer survivors

\begin{tabular}{|c|c|c|c|c|c|}
\hline Cancer type & No. of cases & Sex & $\begin{array}{l}\text { Age at cancer } \\
\text { diagnosis (yr) }\end{array}$ & Age at BMD exam (yr) & BMD \\
\hline \multirow[t]{2}{*}{ Intracranial germ cell tumor ${ }^{45)}$} & 28 & $13 \mathrm{M}$ & $11.5 \pm 2.4$ & $23.1 \pm 4.4$ & Osteoporosis ${ }^{*}$ in $25.0 \%(n=7)$ \\
\hline & & $15 \mathrm{~F}$ & & & Osteopenia in $42.9 \%(n=12)$ \\
\hline \multirow[t]{2}{*}{ Osteosarcoma $^{47)}$} & 40 & $22 \mathrm{M}$ & $15.9 \pm 3.5$ & $22.4 \pm 4.4$ & Osteoporosis ${ }^{*}$ in $47.5 \%(n=19)$ \\
\hline & & $18 \mathrm{~F}$ & $13.9 \pm 5.1$ & $21.2 \pm 6.0$ & Osteopenia* in 30.0\% ( $n=12)$ \\
\hline \multirow[t]{2}{*}{ Hematologic malignancy \& solid tumors ${ }^{58)}$} & 108 & $73 \mathrm{M}$ & $8.9 \pm 4.7$ & $20.3 \pm 3.0$ & $z$-score $<-2.0$ in $16.7 \%(n=18)$ \\
\hline & & $35 \mathrm{~F}$ & & & $-2.0 \leq z$-score $<-1.0$ in $26.1 \%(n=39)$ \\
\hline \multirow[t]{2}{*}{ Hematologic malignancy (ALL, AML, CML) ${ }^{59)}$} & 78 & $34 \mathrm{M}$ & $7.2 \pm 3.8$ & $11.6 \pm 3.4$ & $z$-score $<-2$ in $25.7 \%(n=20)$ \\
\hline & & $44 \mathrm{~F}$ & $7.7 \pm 3.9$ & $13.0 \pm 3.3$ & \\
\hline
\end{tabular}

BMD, bone mineral density; $A L L$, acute lymphoblastic leukemia; $A M L$, acute myeloblastic leukemia; CML, chronic myeloblastic leukemia.

*Definition were as follows; (1) osteoporosis: BMD T-score measured at spine, femur neck, or total body $<-2.5$ ( $\geq 20$ years), $z$-score $<-2.0(<20$ years), (2) osteopenia: $-2.5 \leq$ T-score $<-1.0$ ( $\geq 20$ years), $-2.0 \leq z$-score $<-1.0$ ( $<20$ years). 


\section{Management of CCS with low BMD}

\section{Children's Oncology Group guideline}

The 2018 Children's Oncology Group guideline defined reduced BMD as a $z$-score $>2.0$ standard deviation (SD) below the mean in survivors $<20$ years old or a T-score $>1.0 \mathrm{SD}$ below the mean in survivors $\geq 20$ years old. ${ }^{35)}$ It is recommended that patients at risk of reduced BMD undergo baseline BMD evaluation at entry into long-term follow-up (Table 2). Including those at risk, all CCS should undergo prophylaxis for bone loss and fractures. Adequate intake of calcium (500-1,200 mg/day depending on age), vitamin $\mathrm{D}$ (at least 400 units), and physical activities are suggested as measures to improve bone health of CCS. ${ }^{35)}$ Regular weight-bearing exercise, such as brisk walking, dancing, hopping, jogging, and jumping, and adequate sunlight exposure are also recommended to improve BMD. ${ }^{35)}$ In a 1-year prospective study, a significant increase in total body BMD was observed in children with ALL during the first 3 years after completion of therapy, suggesting the positive effect of long-term completion therapy and increase in physical activity. ${ }^{49)}$ However, most Korean children and adolescents are not achieving the recommended dietary intake of calcium and vitamin $\mathrm{D}^{50)}$ Thus, lifestyle modification should be encouraged

Table 2. Long-term follow-up guideline for childhood cancer survivors who are at risk of reduced BMD

\begin{tabular}{|c|c|c|}
\hline Therapeutic exposure & Potential late effects & Periodic evaluation \\
\hline \multicolumn{3}{|l|}{ Chemotherapy } \\
\hline $\begin{array}{l}\text { Methotrexate } \\
\text { IV (high" or low dose)/IM/PO }\end{array}$ & Reduced BMD & $\begin{array}{l}\text { Bone density evaluation (DXA) } \\
\text { Adjust for height-age z-score in survivors <age } 20 \text { years } \\
\text { Baseline at entry into long-term follow-up, repeat as } \\
\text { clinically indicated. }\end{array}$ \\
\hline \multicolumn{3}{|l|}{$\begin{array}{l}\text { Corticosteroids } \\
\text { Dexamethasone } \\
\text { Prednisone }\end{array}$} \\
\hline \multicolumn{3}{|c|}{ Hematopoietic stem cell transplantation } \\
\hline \multicolumn{3}{|l|}{ Radiotherapy } \\
\hline \multirow[t]{3}{*}{$\begin{array}{l}\text { Head/brain } \\
\text { Total body irradiation }\end{array}$} & GH deficiency & $\begin{array}{l}\text { History } \\
\text { Assessment of nutritional status (every } 6 \text { months until growth is } \\
\text { completed, then yearly) } \\
\text { Physical } \\
\text { Tanner staging (every } 6 \text { months until sexually mature) } \\
\text { Height/weight/BMI (every } 6 \text { months until growth is completed, } \\
\text { then yearly) }\end{array}$ \\
\hline & Gonadotropin deficiency & $\begin{array}{l}\text { History } \\
\text { Onset and tempo of puberty } \\
\text { Sexual function } \\
\text { Medication use (yearly) }\end{array}$ \\
\hline & & $\begin{array}{l}\text { Physical } \\
\text { Tanner staging until sexually mature } \\
\text { Testicular volume (yearly) } \\
\text { Monitor growth until mature (yearly) }\end{array}$ \\
\hline \multirow[t]{2}{*}{ Testis } & Testicular hormonal dysfunction & $\begin{array}{l}\text { History } \\
\text { Onset and tempo of puberty } \\
\text { Sexual function } \\
\text { Medication use (yearly) }\end{array}$ \\
\hline & & $\begin{array}{l}\text { Physical } \\
\text { Tanner staging until sexually mature } \\
\text { Testicular volume (yearly) } \\
\text { Monitor growth until mature (yearly) }\end{array}$ \\
\hline $\begin{array}{l}\text { Pelvis } \\
\text { Spine (whole/sacrum) } \\
\text { Total body irradiation }\end{array}$ & Ovarian hormone deficiency & $\begin{array}{l}\text { History } \\
\text { Onset and tempo of puberty } \\
\text { Menstrual history } \\
\text { Sexual function } \\
\text { Menopausal symptoms } \\
\text { Medication use (yearly) } \\
\text { Physical } \\
\text { Tanner staging until sexually mature } \\
\text { Monitor growth until mature (yearly) }\end{array}$ \\
\hline
\end{tabular}

$\overline{\mathrm{BMD}}$, bone mineral density; IV, intravenous; IM, intramuscular; PO, peroral; DXA, dual energy $x$-ray absorptiometry; GH, growth hormone; $\mathrm{BMI}$, body mass index.

*Any single dose $\geq 1 \mathrm{~g} / \mathrm{m}^{2}$. 
in CCS.

\section{Bisphosphonates in pediatric cancer patients}

Bisphosphonates (BPs) inhibit bone resorption and have been used to treat osteoporosis. The efficacy of BPs was demonstrated in pediatric patients with osteogenesis imperfecta, quadriplegic cerebral palsy, and juvenile rheumatoid arthritis. As in adults, CCS with low BMD are candidates for BPs therapy. For children receiving chemotherapy, the safety and efficacy of BPs are particularly important. Several case series reported the efficacy of BPs on osteoporosis or osteopenia in children with cancer (Table 3). Intravenous infusion of pamidronate increased bone mineral content and alleviated bone pain of pediatric patients with osteosarcoma ${ }^{51)}$ and ALL. ${ }^{52-54)}$ Pamidronate was well tolerated, with few episodes of fever, pain, or symptomatic hypocalcemia. However, the biggest concern is possible interaction of BPs with chemotherapeutic agents. Pamidronate administered with standard chemotherapy was reported to be safe and effective in pediatric patients with ALL and nonHodgkin lymphoma. ${ }^{52-54)}$ The Memorial Sloan Kettering Cancer Center conducted a clinical trial testing the efficacy and safety of pamidronate for osteosarcoma patients. ${ }^{55)}$ Pamidronate was administered with combination chemotherapy comprising high-dose methotrexate, cisplatin, and doxorubicin. Survival analysis showed that pamidronate did not impair the efficacy of chemotherapy and might improve the durability of limb reconstruction. ${ }^{55)}$ In a cohort of 19 pediatric cancer patients, zoledronate was administered safely and appeared to result in improved bone strength and pain control. ${ }^{56)}$ Limited data are available on the use of BPs in children after HSCT. In 19 children with chronic graft-versus-host disease after HSCT, BPs improved BMD. ${ }^{57)}$

\section{Conclusion}

Low BMD is prevalent among CCS diagnosed with different types of cancer. Therapeutic modalities affecting BMD are essential for treating cancer. Thus, periodic evaluations of BMD in CCS should be performed. We need to pay more attention to CCS with many risk factors for reduced BMD, and proper management is needed during therapy as well as after cessation of treatment. Moreover, long-term follow-up is necessary to maintain bone health after cancer treatment. Further studies are required to analyze the efficacy and safety of medication.

\section{Conflicts of interest}

No potential conflict of interest relevant to this article was reported.

\section{References}

1. Chemaitilly W, Cohen LE, Mostoufi-Moab S, Patterson BC, Simmons JH, Meacham LR, et al. Endocrine late effects in childhood cancer survivors. J Clin Oncol 2018;36:2153-9.

2. Brignardello E, Felicetti F, Castiglione A, Chiabotto P, Corrias A, Fagioli F, et al. Endocrine health conditions in adult survivors of childhood cancer: the need for specialized adult focused follow-up clinics. Eur J Endocrinol 2013;168:465-72.

3. Hudson MM, Ness KK, Gurney JG, Mulrooney DA, Chemaitilly W, Krull KR, et al. Clinical ascertainment of health outcomes among adults treated for childhood cancer. JAMA 2013;309:2371-81.

4. van Atteveld JE, Pluijm SMF, Ness KK, Hudson MM, Chemaitilly W, Kaste SC, et al. Prediction of low and very low bone mineral density among adult survivors of childhood cancer. J Clin Oncol 2019;37:2217-25.

5. Sala A, Talsma D, Webber C, Posgate S, Atkinson S, Barr

Table 3. Bisphosphonates treatments in pediatric cancer patients

\begin{tabular}{|c|c|c|c|c|}
\hline Study & Disease & No. of cases & Bisphosphonates & Changes of BMD z-score \\
\hline Lim et al..$^{511}(2016)$ & Osteosarcoma & 9 & Pamidronate & Lumbar spine $+0.108 \pm 0.062$ \\
\hline Barr et al. ${ }^{52)}(2002)$ & Acute lymphoblastic leukemia & 10 & Pamidronate & Total body +0.96 , Lumbar spine +1.11 \\
\hline Goldbloom et al. ${ }^{53)}$ (2005) & Acute lymphoblastic leukemia & 2 & Pamidronate & Total body $+0.7 /+1.02$ at 20 months \\
\hline Lee et al. $^{54)}$ (2013) & $\begin{array}{l}\text { Acute lymphoblastic leukemia } \\
\text { Non-Hodgkin lymphoma }\end{array}$ & 24 & Pamidronate & Lumbar spine +2.06 \\
\hline Meyers et al. ${ }^{55)}$ (2011) & Osteosarcoma & 40 & Pamidronate & NA \\
\hline August et al. ${ }^{56)}$ (2011) & $\begin{array}{c}\text { Neuroblastoma, osteosarcoma } \\
\text { Ewing sarcoma } \\
\text { Undifferentiated sarcoma } \\
\text { DSRCT, Rhabdoid tumor } \\
\text { Primitive neuroectodermal tumor } \\
\text { Rhabdomyosarcoma }\end{array}$ & 19 & Zoledronate & NA \\
\hline Carpenter et al. ${ }^{57)}$ (2007) & Who received HSCT & 18 & Various & +1.77 \\
\hline Lethaby et al. ${ }^{60)}$ (2007) & Acute lymphoblastic leukemia & 15 & Alendronate & Lumbar spine +0.64 \\
\hline Wiernikowski et al..$^{61)}(2005)$ & $\begin{array}{l}\text { Acute lymphoblastic leukemia } \\
\text { Non-Hodgkin lymphoma }\end{array}$ & 10 & Alendronate & $\begin{array}{c}\text { Lumbar spine }+0.51 \\
\text { Total body bone mineral content }+0.49\end{array}$ \\
\hline
\end{tabular}

BMD, bone mineral density; NA, not available; DSRCT, desmoplastic small round cell tumor; HSCT, hematopoietic stem cell transplantation 
R. Bone mineral status after treatment of malignant lymphoma in childhood and adolescence. Eur J Cancer Care (Engl) 2007;16:373-9.

6. Wasilewski-Masker K, Kaste SC, Hudson MM, Esiashvili N, Mattano LA, Meacham LR. Bone mineral density deficits in survivors of childhood cancer: long-term followup guidelines and review of the literature. Pediatrics 2008; 121:e708-13

7. Lewiecki EM, Gordon CM, Baim S, Leonard MB, Bishop NJ, Bianchi ML, et al. International Society for Clinical Densitometry 2007 Adult and Pediatric Official Positions. Bone 2008;43:1115-21.

8. Shuhart CR, Yeap SS, Anderson PA, Jankowski LG, Lewiecki EM, Morse LR, et al. Executive summary of the 2019 ISCD position development conference on monitoring treatment, DXA cross-calibration and least significant change, spinal cord injury, peri-prosthetic and orthopedic bone health, transgender medicine, and pediatrics. J Clin Densitom 2019;22:453-71.

9. Gordon CM, Zemel BS, Wren TA, Leonard MB, Bachrach LK, Rauch F, et al. The determinants of peak bone mass. J Pediatr 2017;180:261-9.

10. Heaney RP, Abrams S, Dawson-Hughes B, Looker A, Marcus R, Matkovic V, et al. Peak bone mass. Osteoporos Int 2000;11:985-1009.

11. Faulkner RA, Davison KS, Bailey DA, Mirwald RL, BaxterJones AD. Size corrected BMD decreases during peak linear growth: implications for fracture incidence during adolescence. J Bone Miner Res 2006;21:1864-70.

12. van der Sluis IM, van den Heuvel-Eibrink MM, Hählen K, Krenning EP, de Muinck Keizer-Schrama SM. Altered bone mineral density and body composition, and increased fracture risk in childhood acute lymphoblastic leukemia. J Pediatr 2002;141:204-10.

13. Inaba $\mathrm{H}, \mathrm{Cao} X, \mathrm{X}$, Han $\mathrm{AQ}$, Panetta JC, Ness KK, Metzger $\mathrm{ML}$, et al. Bone mineral density in children with acute lymphoblastic leukemia. Cancer 2018;124:1025-35.

14. Al-Tonbary YA. Bone mineral density in newly diagnosed children with neuroblastoma. Pediatr Blood Cancer 2011;56:202-5.

15. Holzer G, Krepler P, Koschat MA, Grampp S, Dominkus M, Kotz R. Bone mineral density in long-term survivors of highly malignant osteosarcoma. J Bone Joint Surg Br 2003;85:231-7.

16. Ruza E, Sierrasesumaga L, Azcona C, Patino-Garcia A. Bone mineral density and bone metabolism in children treated for bone sarcomas. Pediatr Res 2006;59:866-71.

17. Müller C, Winter CC, Rosenbaum D, Boos J, Gosheger G, Hardes J, et al. Early decrements in bone density after completion of neoadjuvant chemotherapy in pediatric bone sarcoma patients. BMC Musculoskelet Disord 2010;11:287.

18. De Nijs RN. Glucocorticoid-induced osteoporosis: a review on pathophysiology and treatment options. Minerva Med 2008;99:23-43.

19. Mandel K, Atkinson S, Barr RD, Pencharz P. Skeletal morbidity in childhood acute lymphoblastic leukemia. J Clin Oncol 2004;22:1215-21.

20. van Santen HM, van den Heuvel-Eibrink MM, van de Wetering MD, Wallace WH. Hypogonadism in children with a previous history of cancer: endocrine management and follow-Up. Horm Res Paediatr 2019;91:93-103.

21. Almeida M, Laurent MR, Dubois V, Claessens F, O'Brien CA, Bouillon R, et al. Estrogens and androgens in skeletal physiology and pathophysiology. Physiol Rev 2017;97:13587.

22. Green DM, Nolan VG, Goodman PJ, Whitton JA, Srivastava $\mathrm{D}$, Leisenring $\mathrm{WM}$, et al. The cyclophosphamide equivalent dose as an approach for quantifying alkylating agent exposure: a report from the Childhood Cancer Survivor Study. Pediatr Blood Cancer 2014;61:53-67.

23. Chemaitilly W, Li Z, Krasin MJ, Brooke RJ, Wilson CL, Green DM, et al. Premature ovarian insufficiency in childhood cancer survivors: a report from the St. Jude lifetime cohort. J Clin Endocrinol Metab 2017;102:2242-50.

24. Chemaitilly W, Liu Q, van Iersel L, Ness KK, Li Z, Wilson $\mathrm{CL}$, et al. Leydig cell function in male survivors of childhood cancer: a report from the St Jude lifetime cohort study. J Clin Oncol 2019;37:3018-31.

25. Siegel DA, Claridy M, Mertens A, George E, Vangile K, Simoneaux SF, et al. Risk factors and surveillance for reduced bone mineral density in pediatric cancer survivors. Pediatr Blood Cancer 2017;64:e26488.

26. Stern JM, Sullivan KM, Ott SM, Seidel K, Fink JC, Longton $\mathrm{G}$, et al. Bone density loss after allogeneic hematopoietic stem cell transplantation: a prospective study. Biol Blood Marrow Transplant 2001;7:257-64.

27. Yao S, McCarthy PL, Dunford LM, Roy DM, Brown K, Paplham P, et al. High prevalence of early-onset osteopenia/ osteoporosis after allogeneic stem cell transplantation and improvement after bisphosphonate therapy. Bone Marrow Transplant 2008;41:393-8.

28. Taskinen M, Saarinen-Pihkala UM, Hovi L, Vettenranta K, Mäkitie O. Bone health in children and adolescents after allogeneic stem cell transplantation: high prevalence of vertebral compression fractures. Cancer 2007;110:442-51.

29. Choi HS, Chang EJ, Lee EH, Yang HR. Changes in bone health during the first year of cancer treatment in children. J Clin Densitom 2017;20:25-31.

30. Banfi A, Podestà M, Fazzuoli L, Sertoli MR, Venturini M, Santini G, et al. High-dose chemotherapy shows a dosedependent toxicity to bone marrow osteoprogenitors: a mechanism for post-bone marrow transplantation osteopenia. Cancer 2001;92:2419-28.

31. Le Meignen M, Auquier P, Barlogis V, Sirvent N, Contet A, Simeoni MC, et al. Bone mineral density in adult survivors of childhood acute leukemia: impact of hematopoietic stem cell transplantation and other treatment modalities. Blood 2011;118:1481-9.

32. McClune BL, Majhail NS. Osteoporosis after stem cell transplantation. Curr Osteoporos Rep 2013;11:305-10. 
33. Remes TM, Arikoski PM, Lähteenmäki PM, Arola MO, Pokka TM, Riikonen VP, et al. Bone mineral density is compromised in very long-term survivors of irradiated childhood brain tumor. Acta Oncol 2018;57:665-74.

34. Giustina A, Mazziotti G, Canalis E. Growth hormone, insulin-like growth factors, and the skeleton. Endocr Rev 2008;29:535-59.

35. Children's Oncology Group. Long-term follow-up guidelines for survivors of childhood, adolescent and young adult cancers, Version 5.0 [Internet]. Monrovia (CA): Children's Oncology Group; October 2018 [2019 Jul 10]. Available from: www.survivorshipguidelines.org.

36. Wagner LM, Neel MD, Pappo AS, Merchant TE, Poquette CA, Rao BN, et al. Fractures in pediatric Ewing sarcoma. J Pediatr Hematol Oncol 2001;23:568-71.

37. Paulino AC. Late effects of radiotherapy for pediatric extremity sarcomas. Int J Radiat Oncol Biol Phys 2004; 60:265-74.

38. Mora S, Gilsanz V. Establishment of peak bone mass. Endocrinol Metab Clin North Am 2003;32:39-63.

39. Tillmann V, Darlington AS, Eiser C, Bishop NJ, Davies HA. Male sex and low physical activity are associated with reduced spine bone mineral density in survivors of childhood acute lymphoblastic leukemia. J Bone Miner Res 2002; 17:1073-80.

40. Bloomhardt HM, Sint K, Ross WL, Rotatori J, Ness K, Robinson C, et al. Severity of reduced bone mineral density and risk of fractures in long-term survivors of childhood leukemia and lymphoma undergoing guidelinerecommended surveillance for bone health. Cancer 2020;126:202-10.

41. te Winkel ML, van Beek RD, de Muinck KeizerSchrama SM, Uitterlinden AG, Hop WC, Pieters R, et al. Pharmacogenetic risk factors for altered bone mineral density and body composition in pediatric acute lymphoblastic leukemia. Haematologica 2010;95:752-9.

42. Högler W, Wehl G, van Staa T, Meister B, Klein-Franke A, Kropshofer G. Incidence of skeletal complications during treatment of childhood acute lymphoblastic leukemia: comparison of fracture risk with the General Practice Research Database. Pediatr Blood Cancer 2007;48:21-7.

43. Benmiloud S, Steffens M, Beauloye V, de Wandeleer A, Devogelaer JP, Brichard B, et al. Long-term effects on bone mineral density of different therapeutic schemes for acute lymphoblastic leukemia or non-Hodgkin lymphoma during childhood. Horm Res Paediatr 2010;74:241-50.

44. Pietilä S, Sievänen H, Ala-Houhala M, Koivisto AM, Liisa Lenko H, Mäkipernaa A. Bone mineral density is reduced in brain tumour patients treated in childhood. Acta Paediatr 2006;95:1291-7.

45. Kang MJ, Kim SM, Lee YA, Shin CH, Yang SW, Lim JS Risk factors for osteoporosis in long-term survivors of intracranial germ cell tumors. Osteoporos Int 2012;23:1921-9.

46. Ahn JH, Cho WH, Lee JA, Kim DH, Seo JH, Lim JS. Bone mineral density change during adjuvant chemotherapy in pediatric osteosarcoma. Ann Pediatr Endocrinol Metab 2015;20:150-4

47. Lim JS, Kim DH, Lee JA, Kim DH, Cho J, Cho WH, et al. Young age at diagnosis, male sex, and decreased lean mass are risk factors of osteoporosis in long-term survivors of osteosarcoma. J Pediatr Hematol Oncol. 2013;35:54-60.

48. Othman F, Guo CY, Webber C, Atkinson SA, Barr RD. Osteopenia in survivors of Wilms tumor. Int J Oncol 2002;20:827-33.

49. Marinovic D, Dorgeret S, Lescoeur B, Alberti C, Noel $\mathrm{M}$, Czernichow $\mathrm{P}$, et al. Improvement in bone mineral density and body composition in survivors of childhood acute lymphoblastic leukemia: a 1-year prospective study. Pediatrics 2005; 116:e102-8.

50. Rhee SY, Hwang YC, Chung HY, Woo JT. Vitamin D and diabetes in Koreans: analyses based on the fourth Korea National Health and Nutrition Examination Survey (KNHANES), 2008-2009. Diabet Med 2012;29:1003-10.

51. Lim SW, Ahn JH, Choi A, Cho WH, Lee JA, Kim DH, et al. Efficacy of pamidronate in pediatric osteosarcoma patients with low bone mineral density. Ann Pediatr Endocrinol Metab 2016;21:21-5.

52. Barr RD, Guo CY, Wiernikowski J, Webber C, Wright M, Atkinson S. Osteopenia in children with acute lymphoblastic leukemia: a pilot study of amelioration with pamidronate. Med Pediatr Oncol 2002;39:44-6.

53. Goldbloom EB, Cummings EA, Yhap M. Osteoporosis at presentation of childhood ALL: management with pamidronate. Pediatr Hematol Oncol 2005;22:543-50.

54. Lee JM, Kim JE, Bae SH, Hah JO. Efficacy of pamidronate in children with low bone mineral density during and after chemotherapy for acute lymphoblastic leukemia and nonHodgkin lymphoma. Blood Res 2013;48:99-106.

55. Meyers PA, Healey JH, Chou AJ, Wexler LH, Merola PR, Morris CD, et al. Addition of pamidronate to chemotherapy for the treatment of osteosarcoma. Cancer 2011;117:173644.

56. August KJ, Dalton A, Katzenstein HM, George B, Olson TA, Wasilewski-Masker K, et al. The use of zoledronic acid in pediatric cancer patients. Pediatr Blood Cancer 2011;56:610-4

57. Carpenter PA, Hoffmeister P, Chesnut CH 3rd, Storer B, Charuhas PM, Woolfrey AE, et al. Bisphosphonate therapy for reduced bone mineral density in children with chronic graft-versus-host disease. Biol. Blood Marrow Transplant 2007;13:683-90

58. Han JW, Kim HS, Hahn SM, Jin SL, Shin YJ, Kim SH, et al. Poor bone health at the end of puberty in childhood cancer survivors. Pediatr Blood Cancer 2015;62:1838-43.

59. Choi YJ, Park SY, Cho WK, Lee JW, Cho KS, Park SH, et al. Factors related to decreased bone mineral density in childhood cancer survivors. J Korean Med Sci 2013;28:1632-8.

60. Lethaby C, Wiernikowski J, Sala A, Naronha M, Webber C, 
Barr RD. Bisphosphonate therapy for reduced bone mineral density during treatment of acute lymphoblastic leukemia in childhood and adolescence: a report of preliminary experience. J Pediatr Hematol Oncol 2007;29:613-16.
61. Wiernikowski JT, Barr RD, Webber C, Guo CY, Wright M, Atkinson SA. Alendronate for steroid-induced osteopenia in children with acute lymphoblastic leukaemia or nonHodgkin's lymphoma: results of a pilot study. J Oncol Pharm Pract 2005;11:51-6. 